\title{
Review Paper on Biofuels from Lignin
}

\section{Abstract}

Biofuels are need of present time as fossil fuels are diminishing day by day and we are in search of some alternative to fossil fuels. Biofuels are a medium for getting a prosperous future without pollution. Dawn of Biofuels has already been occur and the day is not so far when each and every vehicle will get driving energy from Biofuel. The forest biorefinery concept involves converting a pulp mill into a multipurpose biofuels, biomaterials, and biopower production facility in which these products are produced in an environmentally compatible and sustainable manner. We will have to enhance quality of Biofuels for making appreciable use of it.

Index Terms: Biofuels, Lignin, Cellulose, Lignoboost

\section{Introduction}

Sustainability is undoubtedly one of the most important cornerstones of energy independence, rendering it desirable to utilize all biomaterial in the most efficient manner. Society's challenge is to not only develop new green technologies and products, but also to help establish commercial practices to become green industrial practices. Biofuels are the one way for producing such energy independence with sustainability.

Biofuels are biomass-based components for transport fuels, which are an interesting sustainable option for the transport sector. Unlike the combustion of fossil fuels which releases $\mathrm{CO} 2$ that was captured several hundred million years ago, $\mathrm{CO} 2$ released by during the utilization of a biomass based fuel is balanced by $\mathrm{CO} 2$ captured in the recent growth of the biomass, resulting in far less net impact on greenhouse gas levels. Since biomass utilization can be considered as a closed carbon cycle, the production and usage of biofuels is expected to reduce the net $\mathrm{CO} 2$ emission significantly. ${ }^{1}$

There is great need of Biofuels in present time because, population is increasing day by day and there is also increase in demand of petroleum and other fuels sources for transportation purpose. The contribution of $\mathrm{CO} 2$ from fossil fuels combustion to climate change has been noted in several recent reviews. Now the question arises that what kind of material shoul we use for Biofuel production? We should use those material as raw material for Biofuel production which, (i) must have high energy content, (ii) must be available in high volumes and (iii) must be easily accessible at a low cost. Lignin is the material which have all these properties.

Lignin is one of the most complex natural polymers in regards its chemical structure and composition. It is formed by oxidative coupling of 4-hydroxyphenylpropanoids (monolignols) that differ in their degree of methoxylation. ${ }^{2}$ Because of its chemical 
composition, lignin is hydrophobic and acts like a coating around the cellulose fibrils. After cellulose, lignin is the second most abundant biopolymer on earth. Biosphere has an estimated $300 \times 10^{\wedge} 9$ metric tons of lignin with a $20 \times 10^{\wedge} 9$ metric tons annual biosynthesis rate. $^{3}$ This polyphenolic polymer is synthesized by enzymatic dehydrogenative polymerization of 4-hydroxyphenyl propanoid units. There are two main theories on lignin biosynthesis: one belief is that the assembly of lignin is controlled biochemically by dirigent proteins, while the other is that after the enzymes dehydrogenate the monoligols to radicals, they randomly couple each other and the growing lignin polymer. ${ }^{4,5}$ The oxidative coupling of 4-hydroxyphenylpropanoid units to form $\beta-\mathrm{O}-4$ ether isomers and dibenzodioxocin respectively. ${ }^{6}$ The phenylpropanoids are linked to each other by various ether and carboncarbon inter unit linkages creating a three-dimensional highly cross-linked polymer.

\section{Review Of Literature}

\subsection{History of Biofuel}

In pre-historic time wood was used as fuel and it may be considered as first form of biofuel.

Main work on biofuels started in 20th centuary. During the period of 1923-1926 two scientists achieved something special. Rudolf Diesel redesigned his diesesl engine to run from peanut oil. Henry Ford designed T-Car which was capable of running on "Hemp derived Biofuel". These two work were milestones in development of Biofuels. After the World War II most European countries had become ruined and this miserable condition acted as catalyst for finding alternatives to fossil and treditional fuels. In context of this Germans started to use mixture of Gasoline \& Alcohol for transportation purpose while in Britain mixture of Grain alcohol \& Petrol became popular. All these steps were taken to reduce cost of fuels. During the period of 1973-1979 fuel crises took place beacause of geopolitical conflicts and OPEC (Organisation of Petroleum Exporting Countries) made heavy cut in exports to non-OPEC countries. As a result, energy crisis took place and then people started thinking seriously about Biofuels. In May,2012 Wang, Hongzhi at "Beijing AgroBiotechnology Research Center" said that Lignin modification improves the biofuel production potential in transgenic Populus tomentosa. They pretreat and enzymatically hydrolysed the mature wood from transgenic poplar plants that expressed the antisense transgene of monolignol biosynthesis. A long term field trial was set for transgenic plant. Beside these efforts, in December, 2008 Goran Gellersteadt found the chemical structures present in biofuels which were obtained from lignin. 1980-2012 is the period when various biotechnological and genetic engineered concepts have been applied to increase biofuel production at lower cost

\subsection{Fossil Fuels vs. Biofuels}

Due to the increasing global energy demand and limited fossil fuel reserves, one of the most daunting challenges facing science in the 21 st century is to deliver solutions for addressing global energy needs in the future in a sustainable manner. ${ }^{7}$ There is also an increasing awareness that the utilization of fossil raw materials and fuels increase the net discharge of carbon dioxide $(\mathrm{CO} 2)$ in the atmosphere and contribute to the "green house effect". 8 Thus, beside the energy problem, the other important challenge is to predict how Earth's ecosystems will respond to global climate change. $\mathrm{CO} 2$ is considered to be the most prevalent greenhouse gas, and the build up of $\mathrm{CO} 2$ causes global climate change. ${ }^{9}$ The desire to maintain sustainable development has led to an increasing interest in society for biofuels and the conversion of renewable biomass resources to liquid fuels. ${ }^{10}$ 


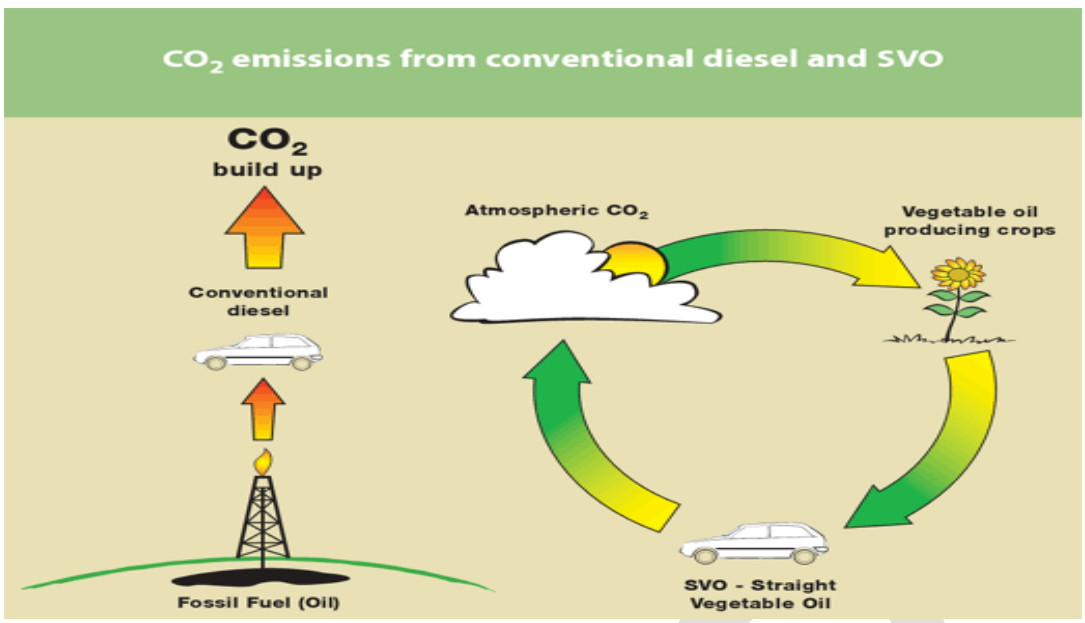

\section{FIG. 1: Production and usage of biofuel reduces Carbon emission significantly}

Until recently, the need for biofuels remained generally a low priority, as petroleum supply and demand curves were satisfactorily addressed. Nonetheless, global petroleum demands have increased steadily from $56.2 \times 106$ barrels/day in 1975 to $85.9 \times 106$ barrels/day in 2007. ${ }^{11}$ The impact of this growth in demand, and limited global production capacity has been foretold by several organizations and individuals. ${ }^{12}$ Coupled with these concerns, the contribution of combustion $\mathrm{CO} 2$ from fossil fuels to climate change has been noted in several recent reviews. ${ }^{13,14}$ The relationship between the greenhouse gas emission produced by human activity and the increase of their average saturation levels in the atmosphere is obvious.

As described by Hoffert et al., future reductions in the ecological footprint of energy generation will reside in multi-faceted approach that includes the use of hydrogen, wind, nuclear, solar power, and fossil fuels (from which carbon is sequestered) and biofuels. ${ }^{15}$ In addition to the need to develop novel green technologies to reduce our carbon emission in the future, existing green and low impact energy generation technologies should be implemented in existing industrial practices. A review by Pacala and Socolov shed light on a portfolio of existing technologies capable of meeting the world's energy needs over the next 50 years and of limiting atmospheric $\mathrm{CO} 2$ to a trajectory that avoids a doubling of the preindustrial concentration. ${ }^{\mathbf{1 6}}$

\subsection{Lignin utilisation for energy production is not a fantasy}

Lignin utilisation for energy production is not a fanatsy and it has become reality in today's scenario. Many companies around the world are utlilising lignin for energy production. It is really very good thing that we can utilise lignin for production of some valuable products at industrial level, because lignin is just a waste product of various industries (mainly Pulp \& Paper Industry waste). Lignin pollutes environment and mainly water bodies which cause a great threat to organisms living in those water bodies and indirectly it can also affect human life. So, it's really great that many industries have identified the importance of lignin utilisation in an environmental friendly manner. Beside this, lignin utilisation have another advatage that if industries become able to produce benefit from waste product that means it is just like ice on cake for them. 
Following is the detail of such industries:-

\begin{tabular}{|c|c|c|c|c|c|c|}
\hline $\begin{array}{l}\text { S. } \\
\text { No. }\end{array}$ & $\begin{array}{l}\text { Company } \\
\text { Name }\end{array}$ & Location & Product & $\begin{array}{l}\text { Raw } \\
\text { Material }\end{array}$ & $\begin{array}{l}\text { Pretreatmen } \\
\mathbf{t}\end{array}$ & Fate of Lignin \\
\hline 1. & Abengoa & Spain & $\mathrm{EtOH}$ & $\begin{array}{l}\text { Wheat } \\
\text { Straw } \\
\text { (WS) }\end{array}$ & $\begin{array}{l}\text { Enzymatic } \\
\text { Hydrolysis }\end{array}$ & $\begin{array}{l}\text { Co-Product } \\
\text { recovered after } \\
\text { distillation }\end{array}$ \\
\hline 2. & Inbicon & Denmark & $\mathrm{EtOH}$ & WS & $\begin{array}{l}\text { Liquid hot } \\
\text { water }\end{array}$ & $\begin{array}{l}\text { Solid biofuel for } \\
\text { power plant }\end{array}$ \\
\hline 3. & Logen & Canada & $\mathrm{EtOH}$ & $\begin{array}{l}\text { WS, Barley } \\
\text { Straw }\end{array}$ & $\begin{array}{l}\text { Steam } \\
\text { Explosion }\end{array}$ & $\begin{array}{l}\text { For steam and } \\
\text { electricity } \\
\text { generation }\end{array}$ \\
\hline 4. & $\begin{array}{l}\text { KL } \\
\text { Energy }\end{array}$ & USA & $\mathrm{EtOH}$ & $\begin{array}{l}\text { Card board } \\
\& \text { paper }\end{array}$ & $\begin{array}{l}\text { Thermo- } \\
\text { mechanical }\end{array}$ & $\begin{array}{l}\text { For steam \& } \\
\text { electricity } \\
\text { generation }\end{array}$ \\
\hline 5. & SEKAB & Sweden & $\mathrm{EtOH}$ & $\begin{array}{l}\text { Wood } \\
\text { Chips }\end{array}$ & $\begin{array}{l}\text { Acid } \\
\text { Pretreatment }\end{array}$ & $\begin{array}{l}\text { Energy production } \\
\text { after hydrolysis }\end{array}$ \\
\hline 6. & $\begin{array}{l}\text { Verenium } \\
\text { process }\end{array}$ & USA & EtOH & Switchgrass & $\begin{array}{l}\text { Mid acid } \\
\text { hydrolysis \& } \\
\text { steam } \\
\text { explosion }\end{array}$ & $\begin{array}{l}\text { Burned for steam } \\
\text { generation }\end{array}$ \\
\hline 7. & $\begin{array}{l}\text { Range } \\
\text { Fuel }\end{array}$ & Georgia & EtOH & Grass & $\begin{array}{l}\text { Thermo- } \\
\text { chemical }\end{array}$ & Energy production \\
\hline 8. & $\begin{array}{l}\text { POET } \\
\text { LLC }\end{array}$ & $\begin{array}{l}\text { Emetsbu } \\
\text { rg IA }\end{array}$ & $\mathrm{EtOH}$ & Corn cob & $\begin{array}{l}\text { Thermo- } \\
\text { chemical }\end{array}$ & Biogas Production \\
\hline
\end{tabular}

\subsection{Types of Biofuels}

There are basically 2 types of Biofuels:-

\section{First generation biofuels}

2. Second generation biofuels

First generation biofuels are also called conventional biofuels. These are made up from sugar, starch, and vegetable oil. Example of such first generation biofuels are following:-

Bioalcohols e.g. ethanol

$>$ Biodiesel produced from oils or fats using transesterification

$>$ Vegetable oil e.g. lower quality oil

$>$ Bioethers e.g. oxygenated fuels

$>$ Biogas and methane in compressed form

$>$ Syngas, produced by partial combustion of biomass 
Solid biofuels e.g. dried manure

Second generation biofuels are also called advanced biofuels and these are made up of sustainable feedstocks. Examples of such advanced biofuels are following:-

Algae fuel

$>$ Biohydrogen, Biomethanol etc.

\subsection{Advantages of Biofuels}

Biofuels have a lot of adavantages on traditional fuels or fossil fuels. Some of the advantages are listed below:-

i. Cheaper than fossil fuel - Reason for their low cost is that Govt. offers tax incentives to buy cars running on biofuel e.g. ethanol

ii. Carbon Neutral in nature- They are called so because in usage of Biofuels no extra carbon is generated, reason for this is that when we use Biofuels then a closed cycle of carbon di-oxide is being formed which ensures no extra generation of carbon di-oxide, while this is not the same case in terms of fossil fuels(where an open cycle is being formed, which in turn pollutes the environment).

iii. Less particulate pollution- Amount of suspended particulate materials(SPM) release is also very less in case of Biofuels.

iv. Renewable source of energy- Yes, it is true because plants can be grown again and again which are the main source of biofuels. This is most supreme advantage of biofuels over fossil fuels.

\section{v. Prevention of engine knocking}

vi. High energy density- It means low volume of fuels can produce comaparatively more energy which realy a splendid thing. Another advantage is that it is not diffusive like solar energy and wind energy, which is just like as ice on cake.

\subsection{Sources of Biofuels}

There may be various sources of Biofuels. Any renewable source which is also bio based can be considered as potential source of biofuels. Some of such sources are given below:-

i. Lignin- It may come from two sources one from pulp \& paper industry and other from kingdom plantae e.g. trees, grasses etc. Utlilising lignin from pulp and paper industry would be more benefecial beacause it will cause reduction of pollutant waste material with generation of something valuable product such as biofuel along with economical advantage.

ii. Cellulosic biomass e.g. bagasse

iii. Biodiesel feedstock e.g. animal fats, vegetable oils, soy, rapeseed- Biodiesel is produced after transesterification process, which is a sophisticated process along with special requirement of instrumentation.

iv. Solid biofuels- These may include following things-

a) Domestic refuse- Examples are vegetables, fruits etc.

b) Dried manure

c) Charcoal, agricultural waste etc. 
2.7. What is Lignin?

Lignin is one of the most complex natural polymers in regards its chemical structure and composition. It is formed by oxidative coupling of 4-hydroxyphenylpropanoids (monolignols). There are three phenyl propane precursors of lignin:-

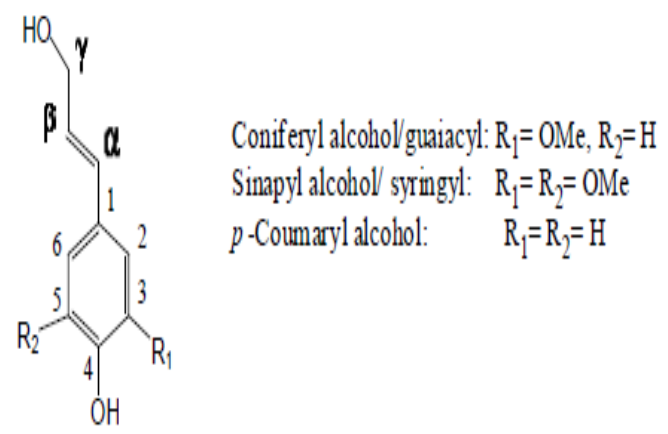

\section{FIG 2: Three Building blocks of Lignin}

These three basic units of lignin combines with each other and form a very complex structure which is three dimensional in nature. When basic units of lignin combines with each other then they form structure shown as below in figure $3 .^{17}$

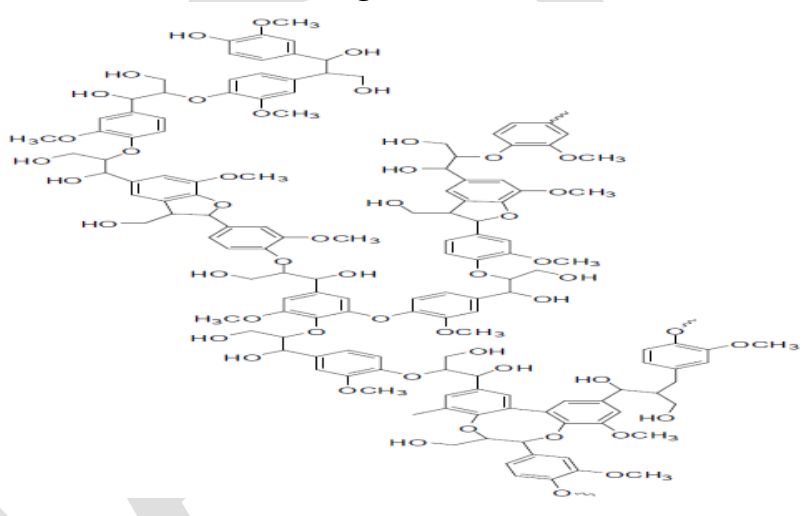

\section{FIG 3: Structure of Lignin}

Lignin is basically the cementing material in plant. It joins the various cellulosic and hemicellulosic materials in plant. Lignin imparts strength to plant. It is also responsible for providing pathogenic resistant properties to plant. Arrangement of lignin in plant along with cellulosic and hemicellulosic bundles has been shown in below figure $4 .^{\mathbf{1 8 , 1 9 , 2 0}}$

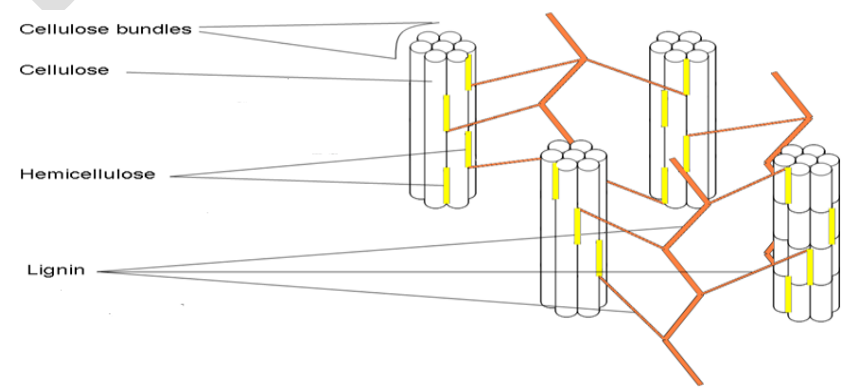

FIG 4: Arrangement of Lignin, Cellulose and Hemicellulosic bundles in plant 


\subsection{Why to choose lignin as a raw material for biofuel production?}

There are various reasons which makes lignin as a favorite raw material for production of biofuel. Some of these reasons are as following:-

1. It is abundant in nature (found in kingdom plantae).

2. It can be obtained as a waste product from Pulp and Paper Industry.

3. It has high energy bonds( Bond breaking will cause energy release).

4. Pollution control, because many industries discharge it as a waste and which in turn may cause water pollution.

\section{Methodology}

\subsection{Methods for obtaining Lignin from various processes.}

Lignin is obtained by various processes e.g. LignoBoost which causes precipitaion of Lignin by its acidification. It utlises the concept that Lignin becomes precipitated in acidic conditions. Acidification of Lignin is done by carbon dioxide at industrial level and lab scale it can be precipitated by sulphuric acid and also with hydrochloric acid.

\subsubsection{LignoBoost Process}

This process reduces the heat of combustion of the BL before it is burned in the recovery boiler by removing a fraction of the lignin in BL thus, the lignin can be exported from the process and used in other applications. The application of this process involves acidification of an alkaline cooking liquor with $\mathrm{CO} 2$, precipitation, filtration and washing. ${ }^{21,22,23}$ Fig 5 shows the schematic diagram of the lignin extraction process by Ligno Boost.

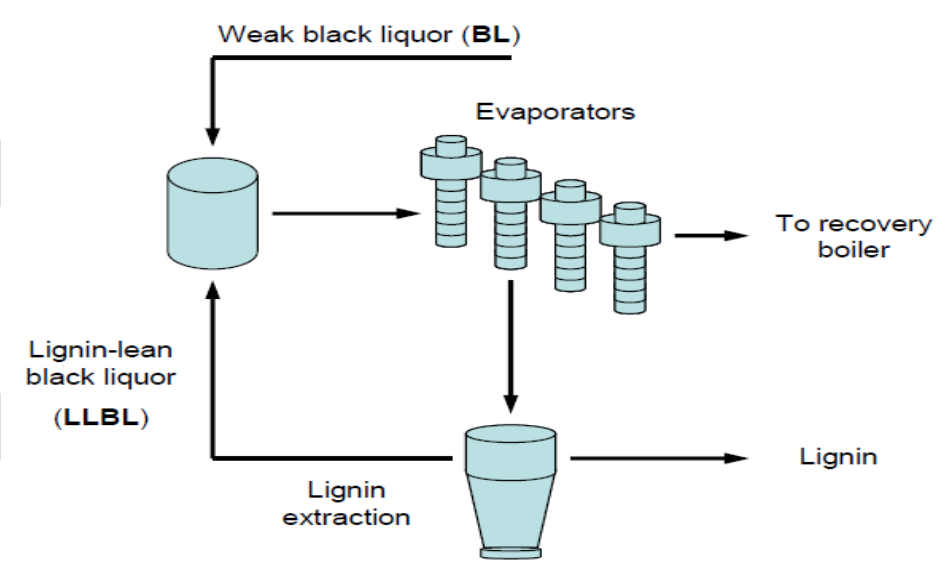

FIG 5: LignoBoost Process

A green process referred to as "LignoBoost" provides a viable separation of lignin from kraft cooking liquors by employing carbon-dioxide to precipitate lignin from alkaline solutions.

In this process "acidification of alkaline cooking liquor" with $\mathrm{CO} 2$ is done which in turn causes the precipitation of Lignin. After this filtration \& washing of precipitated Lignin is done to obtain pure Lignin.

\subsubsection{LignoBoost Purification Step}

Lignin obtained after LignoBoost process is purified by this method. 


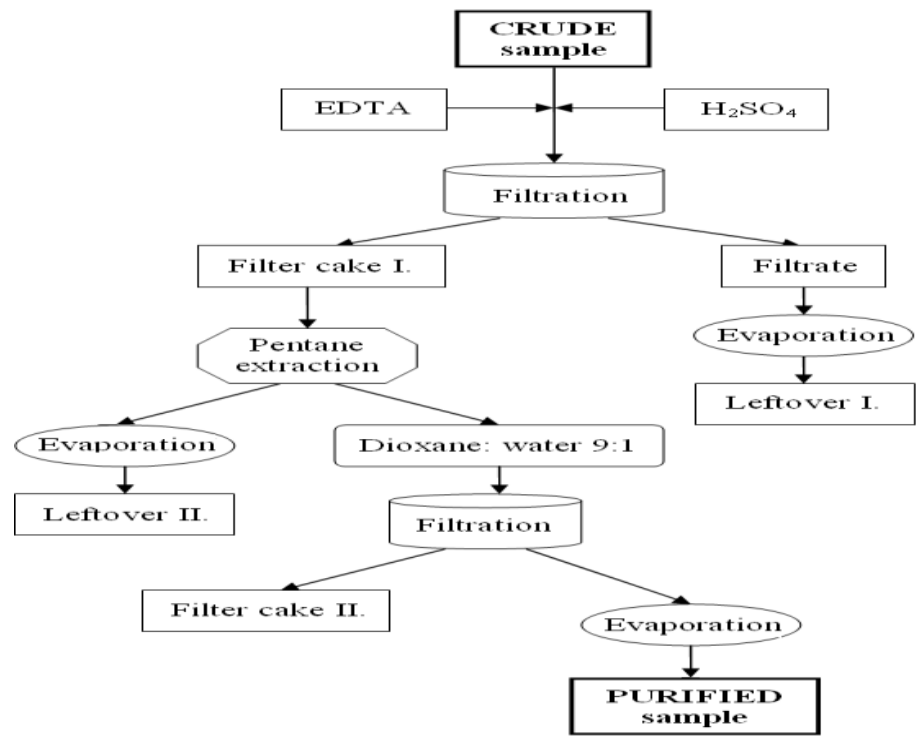

\section{FIG 6: Lignin separation and purification from LignoBoost black liquor precipitate}

For detailed structural analysis of the unwashed lignin samples isolated in LignoBoost process, additional purification is required. The initial LignoBoost samples is diluted in DW to $5 \mathrm{wt} \%$ solid content. Next EDTA-2Na+ is added to the aqueous solution $(5.00 \mathrm{~g} \mathrm{~L}-1)$ to facilitate metal-ion removal and the $\mathrm{pH}$ is adjusted to a value of 6 with aqueous sulfuric acid ( $2 \mathrm{M}$ ) and stirred for $1 \mathrm{~h}$ at RT. Subsequently, the $\mathrm{pH}$ is further lowered to a value of 3 facilitating lignin precipitation. ${ }^{24}$ The resulting samples are frozen $\left(-20^{\circ} \mathrm{C}\right)$ over night, thawed and filtered through medium sintered glass funnel at $0^{\circ} \mathrm{C}$. Retentates are mixed with $\mathrm{pH} 3$ aqueous sulfuric acid solution up to $5 \mathrm{wt} \%$ and the filtration process was repeated three times for effective salt removal. All filtrates are collected, the solvent is removed under reduced pressure and the remaining solid provided the salt fraction. Retentates are air dried, Soxhlet extracted with pentane to remove free sulfur and dissolved in p-dioxane:water (9:1) solution ( $1 \mathrm{~g}$ per litre). After filtration through a medium sintered glass funnel the solvent was removed under reduced pressure. The resulting solid provided purified lignin samples which are stored in a freeze dried form at $-20^{\circ} \mathrm{C}$ until analysis. Fig 6 depicts the flow diagram of the lignin purification process used. ${ }^{\mathbf{2 5}}$

\subsection{Pyrolysis of Purified Lignin}

Purified Lignin obtained by above mentioned purification step can be used as solid biofuel and it can also be burnt at higher temperature to convert it into bio-oil or pyrolysis oil which can be used in motor vehicles for transportation purposes. Pyrolysis of biomass sample is done at $400^{\circ} \mathrm{C}$.

Steps for this are being listed as following:- ${ }^{25}$

i. Biomass or purified lignin is kept on heating element for 2 minutes.

ii. Char is formed.

iii. Char is removed by sweeping arm fixed to reactor.

iv. Another sample is dropped on plate in amount of $50 \mathrm{mg}-1.2 \mathrm{~g}$.

v. Helium gases is used to maintain inert environmentand gases are formed.

vi. Gases formed are fed to condenser and condenser is heated to room temperature

vii. Bio-oil samples are collected 
3.3 Utilization of Lignin after pulping process for the production of biofuel

In Pulp \& Paper industries, Lignin is obtained after Pulping process. Lignin is obtained in two forms, i.e. Dissolved Lignin and Residual Lignin. Dissolved lignin is discarded with black liquor while Residual lignin remains within pulp. Both forms of Lignin can be utilized for production of Biofuels. Various modifications reactions are also required prior to using these types of lignin in biofuel production. Following are the example of such modification reactions:-

a) Hydrothermal Decarboxylation

b) Carbonization

c) Hydrogenolysis

d) Hydrogenation etc.

\subsubsection{Lignin Hydrogenation and Hydrogenolyis}

During hydrogenolysis, the hydrogen is utilized for the cleavage of $\mathrm{C}-\mathrm{O}$ interlignin linkages. During hydrogenation, carbon-carbon or a carbon-oxygen double bonds is saturated by hydrogen: the $\mathrm{H} / \mathrm{C}$ ratio is elevated, but depolymerization does not occur.

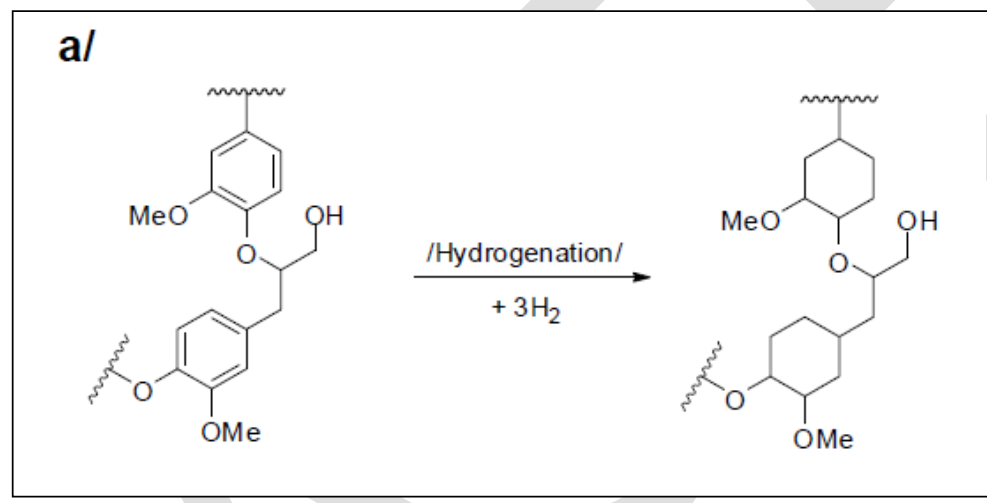

b/
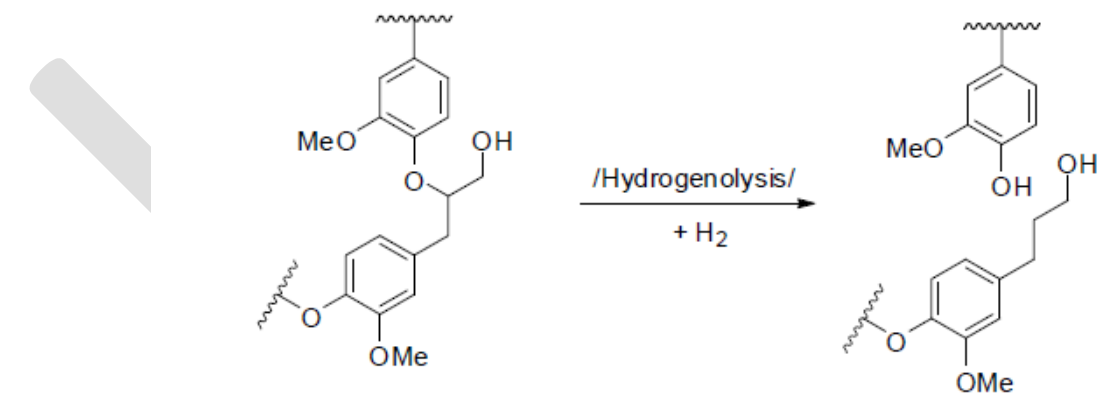

FIG 7. Example for hydrogenation (a) and hydrogenolysis (b) of a $\beta-0-4$ lignin dimer

Previous lignin hydrogenation studies employed either high temperatures $\left(>\mathbf{2 0 0}{ }^{\circ} \mathrm{C}\right)$ and/or high $\mathrm{H} 2$ pressures (>7 MPa), or strong acidic or basic media. Depending on the reaction conditions, up to $60-80 \%$ conversion of the starting lignin to liquefied mixtures was obtained. These mixtures contained hydrogenated products such as $o$ - and $p$-cresol, phenol and $p$ ethyl phenol. ${ }^{26,27,28}$ The knowledge concerning the chemical mechanisms involved in these harsh conditions, the reusability of the catalyst, and tailoring the selectivity of the hydrogenation towards specific lignin groups is improved. 
Recent hydrogenation studies with colloidal Ru or mono-, di- and tetra-nuclear Ru-Arene complexes as catalyst on milled wood lignin indicate that a $50 \%$ decrease in DP can be accomplished. However these catalyst systems are designed for the hydrogenation of the aromatic ring in the lignin polymer, the decrease in DP during the hydrogenation suggests that hydrogenolysis of the biopolymer also happened simultaneously. ${ }^{29,30}$

\begin{tabular}{|c|c|c|c|}
\hline Ru catalyst system* & Ru conc. $[\mathrm{mM}]$ & Time [h] & Conversion (\%) \\
\hline $\mathrm{RuCl}_{3} .3 \mathrm{H}_{2} \mathrm{O} / 3.5 \mathrm{TOA}$ & 3.0 & 24 & 56.4 \\
\hline $\mathrm{RuCl}_{3} .3 \mathrm{H}_{2} \mathrm{O} / 3.5 \mathrm{TOA}$ & 3.0 & 96 & 64.9 \\
\hline $\mathrm{RuCl}_{3} \cdot 3 \mathrm{H}_{2} \mathrm{O} / 7 \mathrm{TOA}$ & 1.5 & 24 & 33 \\
\hline $\mathrm{RuCl}_{3} .3 \mathrm{H}_{2} \mathrm{O} / 3.5 \mathrm{TOA} / \mathrm{TPPMS}$ & 1.9 & 24 & 21 \\
\hline $\mathrm{RuCl}_{3} .3 \mathrm{H}_{2} \mathrm{O} / 3.5 \mathrm{TOA} / \mathrm{TPPMS}$ & 1.9 & 72 & 48 \\
\hline $\mathrm{Ru}_{2} \mathrm{Cl}_{4}\left(\mathrm{C}_{6} \mathrm{Me}_{6}\right)$ & 2.2 & 24 & 5 \\
\hline $\mathrm{Ru}_{2} \mathrm{Cl}_{4}\left(\mathrm{C}_{6} \mathrm{Me}_{6}\right) / 3 \mathrm{Na}_{2} \mathrm{CO}_{3}$ & 0.7 & 72 & 5 \\
\hline
\end{tabular}

\section{Table 1: Extent of aromatic hydrogenation of a mill wood lignin catalyzed by various}

\section{Ru systems}

Hydrogenation with phosphine ligand containing ruthenium complexes of carbon carbon double bond and/or carbon-oxygen bond containing chemicals has provided additional insight on how to tailor the catalytic selectivity towards carbon-oxygen bond cleavage over carboncarbon double bond hydrogenation. The expectation is that selective hydrogenolysis of lignin leads to potential fuel precursors or other value added chemicals by oxygen decrement and hydrogen increment and to products with lower molecular weight by reductive cleavage of C$\mathrm{O}-\mathrm{C}$ bonds. Despite the extensive research, lignin still has a low commercial value and only combusted as a low grade fuel.

\subsubsection{Lignin Liquification}

Lignin liquefaction is mainly conducted on high temperatures by flash pyrolysis. While there are a variety of catalytic and non-catalytic pyrolysis techniques for biomass and lignin liquefaction, flash pyrolysis techniques are conducted primarily at relatively high temperatures: $300-500^{\circ} \mathrm{C}$ with a short resident time only ranging between $1-90$ minutes.

\begin{tabular}{|c|c|c|c|c|c|}
\hline Staring material & Technique & $\begin{array}{c}\mathrm{T} \\
{\left[{ }^{\circ} \mathrm{C}\right]}\end{array}$ & $\begin{array}{c}\text { Gas } \\
\text { /pressure }\end{array}$ & $\begin{array}{l}\text { Space } \\
\text { time } \\
\text { [min] }\end{array}$ & $\begin{array}{c}\text { Bio-oil } \\
\text { yield } \\
{[\%]}\end{array}$ \\
\hline Pinus insignis, & $\begin{array}{c}\text { Fast pyrolysis } \\
\text { (Zeolite: HZSM-5) }\end{array}$ & 400 & $\mathrm{~N}_{2} /$ Atm. & 5 & 64 \\
\hline $\begin{array}{l}\text { Raw pyrolytic bio-oil } \\
\text { (SW) }\end{array}$ & $\begin{array}{c}\text { Fast pyrolysis } \\
\text { (Zeolite: HZSM-5) }\end{array}$ & 450 & Atm. & 30 & 86 \\
\hline Thio lignin* & $\begin{array}{c}\text { High pressure } \\
\text { catalytic hydrogenation }\end{array}$ & $\begin{array}{l}400- \\
450\end{array}$ & $\mathrm{H}_{2} / 200$ bar & 30 & 80 \\
\hline Eucalyptus gummifera & Carbonization & 400 & Sealed & 90 & 52 \\
\hline
\end{tabular}

* Precipitated from $\mathrm{BL}$ with flue gas $\left(\mathrm{CO}_{2}\right)$ at $\mathrm{pH} 8.5$.

Table 2: Bio-oil yields in case of different lignin and lignocellulosic liquefaction techniques with reaction conditions. 
During the catalytic liquefaction of lignin retrieved from BL, it is important thatnthe catalyst not be deactivated by sulfur. Since the sulfur content in lignin obtained from BL can be as high as 5\%, conventional commercial catalyst such as nickel, molybdenum and copper can not used. ${ }^{31}$ Another requirement is that the activity of the catalyst should be high enough so that the reaction does not stop at tar formation, which is the first stage reaction, but advances to tar decomposition, which is the second stage during pyrolysis. ${ }^{32}$ With recent advances in the control of feedstock, water content, temperature ramping and control of the space and time on stream, most of the problems created by coke formation can be avoided. ${ }^{\mathbf{3 3}, 34}$

Given that novel pyrolysis yields ranging between 60 and $80 \%$ and the produced biomass pyrolysis oil has heating values between $16-18 \mathrm{MJ} \mathrm{kg-1}$ on dry basis, it is of great interest in the valorization of the bio-oils as a fuel or fuel substitutes. However the use of crude biomass pyrolysis oil as fuel for diesel engines has several limitations. The oils produced by the pyrolysis of biomass, due to the high levels of oxygen, may be highly viscous and corrosive, relatively unstable and may exhibit a poor heating value. ${ }^{35}$ As a low-cost solution that avoids the adaptation and technological modifications of diesel engines, these limitations can be partially solved by preparing bio-oil/diesel emulsions.

Despite the extensive research on this field, there are still serious limitations such as; $\mathrm{pH}$ in the range of 2.5-3.4, high corrosiveness and instability. Thus, before pyrolytic oils can be used as a regular fuel, it is essential to upgrade the crude bio-oil to impart favourable fuel properties. There is a wide variety of reaction mechanisms published in the field of upgrading of pyrolytic oils and they are essentially involve the removal of oxygen. Promising methods for upgrading pyrolytic oils involves reactions, such as deoxygenation, decarboxylation and decarbonylation of the oil constituents, as well as cracking, oligomerisation, alkylation, isomerisation, cyclisation and aromatization. ${ }^{\mathbf{3 6}}$

\subsection{Problems associated wth Biofuel Production}

Pretreatment step is biggest problem in Biofuel production, because of the following reasons:-

(i) It is time consuming process.

(ii) Require to maintain specific conditions. Require special instruments for optimization which in turn cause increase in cos of production of Biofuels.

(iii)Lengthier the biofuel producing process, lesser will be the yield, because each step isn't $100 \%$ efficient. So it will cause enhancement of errors in biofuel production.

(iv) Extra efforts are required for catalyst recycling.

(v) Special attention is required for waste treatment.

(vi)There is need to check inhibitors formation. Which require continuous monitoring because inhibitors always have negative effects on any process.

\subsubsection{Possible ways to eliminate pretreatment steps}

Pre treatment steps various disadvantages and these steps are seriously time consuming. We have discussed all these points in above section. So, it seems obvious that there is great need to avoid these pre treatment steps in process of biofuel production. By avoiding pretreatment steps we can produce biofuel at much lesser cost $\&$ in lesser time.

\section{Possible ways to avoid pretreatment steps are:-}




\section{a. Applying genetic engineering concepts:-}

\section{Explanation:-}

Main task of pre treatment step is to enhance amount of biomass(in this case it is lignin), for more production of biofuels. We know which genes are responsible for lignin biosynthesis in plant.Genes responsible for Lignin synthesis are, COMT (Cafeate O- Methyltransferase); CCoAOMT and 4CL. ${ }^{37}$ If COMT, CCoAOMT \& 4CL is overexpressed then Lignin's amount will increase and effect of this genetic modification will be:-

(i) Bioenergy crop such as hybrid Poplar will become Drought tolerant.

(ii) Raw material for biofuel will become resistant to pest and insects.

Amount of lignin in plants will also be increased and raw material availability will be enhanced which in turn will cause lower cost of biofuel production, which will be a remarkable achievement for future perspective. Computational biology will play major role in this. Through computational biology we can know more about coding and non-coding part of genes and can enhance effects of coding part.

\section{b. Applying concepts of RDT(Recombinant DNA Technology):}

\section{Explanation:-}

Tailored recombinant microoraganisms means, which are containing both their natural DNA along with artificial DNA(prepared by RDT techniques). Those modified superior microoraganisms will be allowed to act on biomass i.e plant material and will cause separation of lignin from cellulosic and hemicellulosic material. The same work is done in pre treatment steps. So, there will be no requirement of pre treatment steps and there will be escaping of extra time as well as extra cost, which will lead to a clear biofuel at lower cost. Again, for the tailoring of micro-oraganisms there will be great need of Computational Biology.

\subsubsection{Self proposed schemes for escaping pre-treatment steps \& their advantages}

In nature there are several insects which feed on wood for their nutrition. If they are feeding on wood means they will have to degrade all the components of wood i.e. Celluloses, Hemicelluloses and Lignin. Among all these constituents of wood, Lignin has most complex structure and which in turn makes it difficult to degrade it. Nature has provided wood eating insects a special type of enzymes called phenyl oxidases. These enzymes have capability to degrade complex structure of lignin. There are some bacteria also which have capability to produce these enzymes. Example of such bacteria include Actinobacteria, Acidobacteria, Proteobacteria, Streptomyces viridosporus. ${ }^{38}$

These bacteria are anaerobic in nature so there is no requirement of oxygen for there working. Natural habitat of these bacteria is basically the gut of wood eating insects. We can identify the genes responsible of production of phenyl oxidases with the help of various computational biology tools such as BLAST, FASTA Format etc. Once the gene responsible for phenyl oxidases has been identified then we can also know that which part or which sequence of gene is responsible for phenyl oxidase's production. We have various biotechnological advanced tools through which we can enhance their expression upto an appreciable amount. So more phenyl oxidases would be there and more lignin degradation will take place. All these efforts will lead to escaping of various time consuming and energy 
intensive processes such as decarboxylation, hydrogenation and hydrogenolysis.

This would lead to cut in cost for biofuel production, which is major prime concern for making uses of biofuels at commercial level and to make an easy reach of biofuel to each and every person. These approaches along all the above mentioned advantages has been shown in below figure:-

\section{Self Proposed scheme for escaping pretreatment steps \& their advantages}

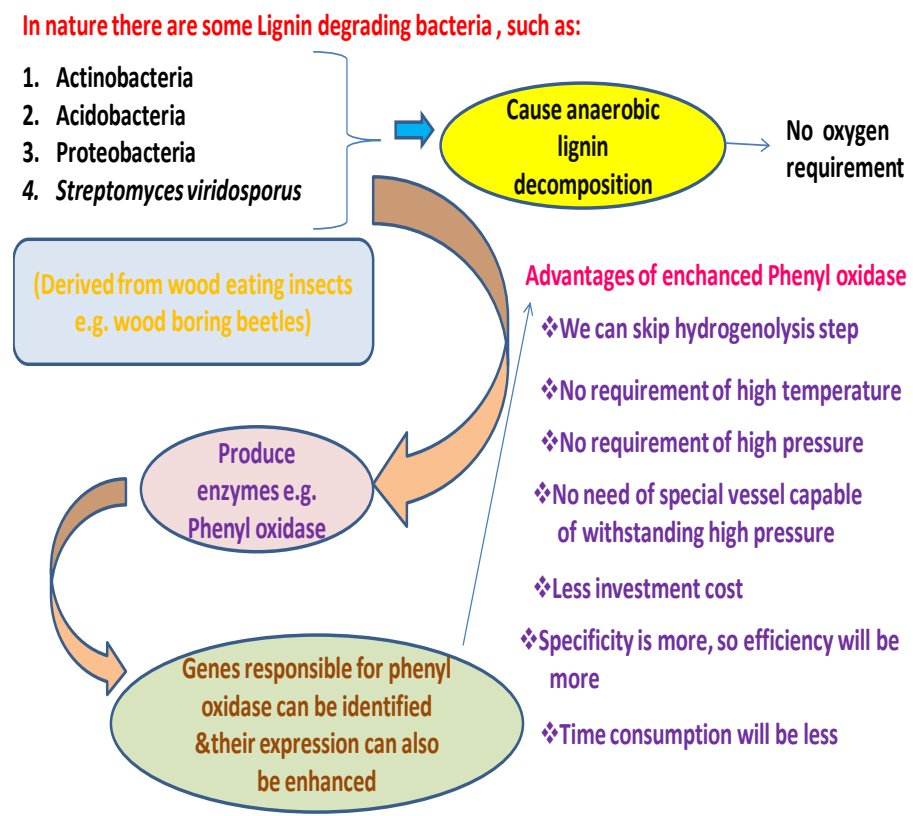

\section{FIG 8:- Self proposed approach for avoiding pre-treatment steps in biofuel production}

\subsection{Different strategies for utilising Lignin in Biofuel production}

There are basically two strategies of obtaining lignin for biofuel production. We can take two sources for lignin. Either we may use agricultural wastes oe domestic wastes as a source of lignin or we may use any industrial effluent streams conating lignin, example of such industrial effluent is Black liquor from pulp and paper industry. Advantage of using industrial effluents is that we don't require treatment steps for seperation of lignin from cellulosic and hemicellulosic bundles. But such treatment steps will be neceassary in case of domestic and agricultural waste product. So, it is obvious that using industrial effluents will be less laborious and we may get higher yeild of desired product which is biofuel in our case.

Following is the figure which shows that how these two strategies are different from each othersalong with their comparative analysis of advantages and disadvantages.

Advantages of using industrial effluent as a source of lignin includes following points:-

(i) Less costlier approach because there is no need of seperating lignin from cellulosic and hemicellulosic bundles.

(ii) Environmental friendly process, beacause we are utilising industrial efflents which may be discarded into water bodies, so we are utilising waste product in an productive 
(iii) Less time consuming process.

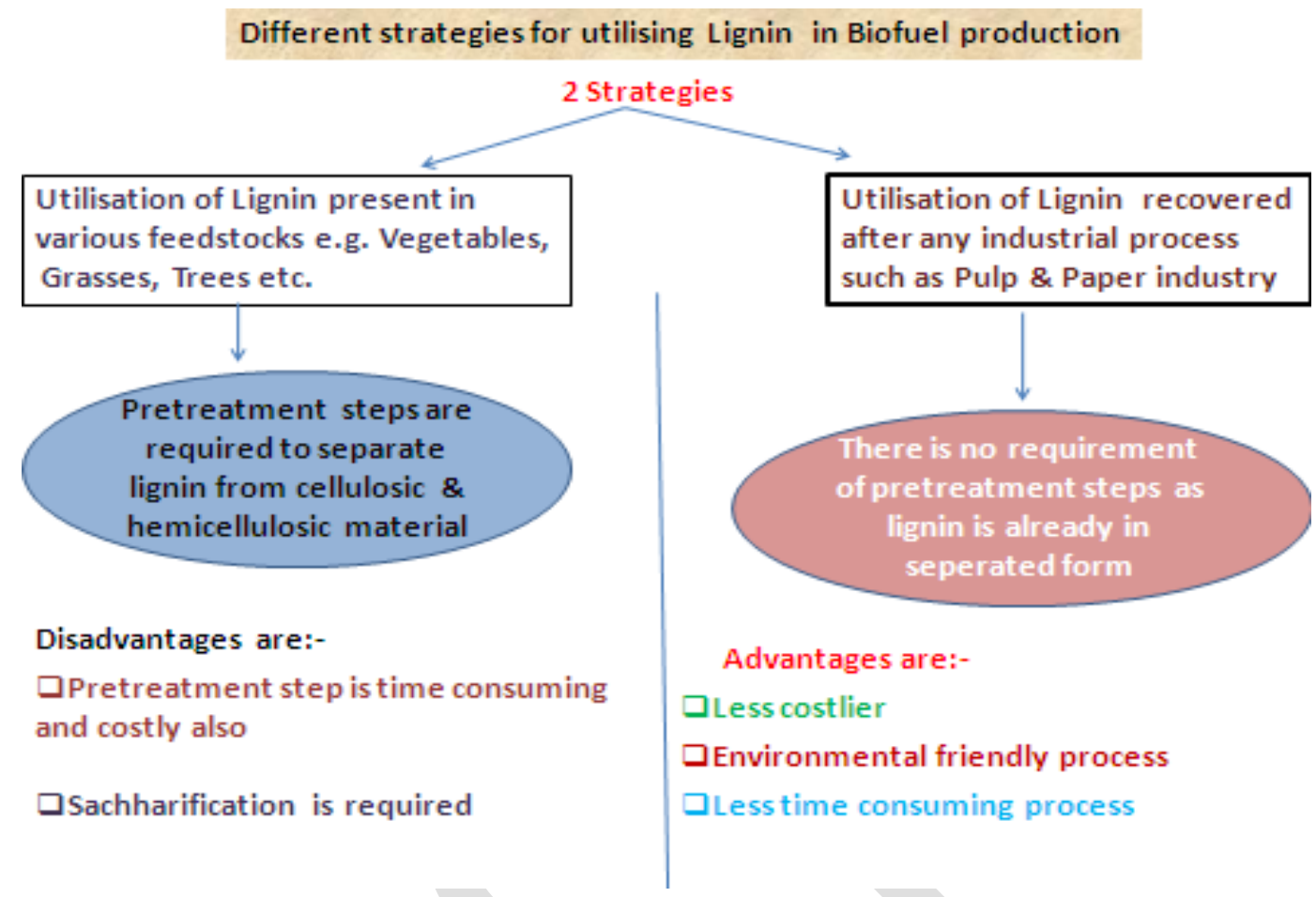

\section{Economical Advantages of Producing Biofuel from Lignin}

When biofuel is being produced from lignin then some extra economical valuable products may also get produced. Example of such products include Vanillin, Vanillic acid, dispersing agents.A flow sheet of the proposed process is shown in figure 10. Aportion of the byproduct stream, black liquor, is processed to extract the lignin. This extraction can be done by the traditional acidification/precipitation method followed by separation, or by using alternative methods such as the one developed by the Swedish group and known as LignoBoost. ${ }^{39}$ After obtaining the purified lignin, the subsequent process is based on three main steps.

The first step is the alkaline lignin oxidation performed in a bubble column reactor. ${ }^{40}$ Thereafter, the obtained mixture passes through amembrane ultrafiltration system where the lignin higher molecular residues are retained. Sodium vanillate and other low molecular weight species go to the permeate stream. ${ }^{41}$ Finally, the permeate containing smaller molecules and excess $\mathrm{NaOH}$ flows through a packed bed with an acid resin, in order to convert the sodium vanillate into vanillin. ${ }^{42}$ This ion-exchange step is accompanied by a neutralization reaction thus originating an exit stream with lower $\mathrm{pH}$. The degraded lignin resulting fromthe membrane process appears as a by-product in the flowsheet. Our purpose is to valorise this material by obtaining lignin-based polyurethane products, e.g., rigid foams, elastomers, sealants, ${ }^{43}$ and additionally biofuels for the related unit operations.. 


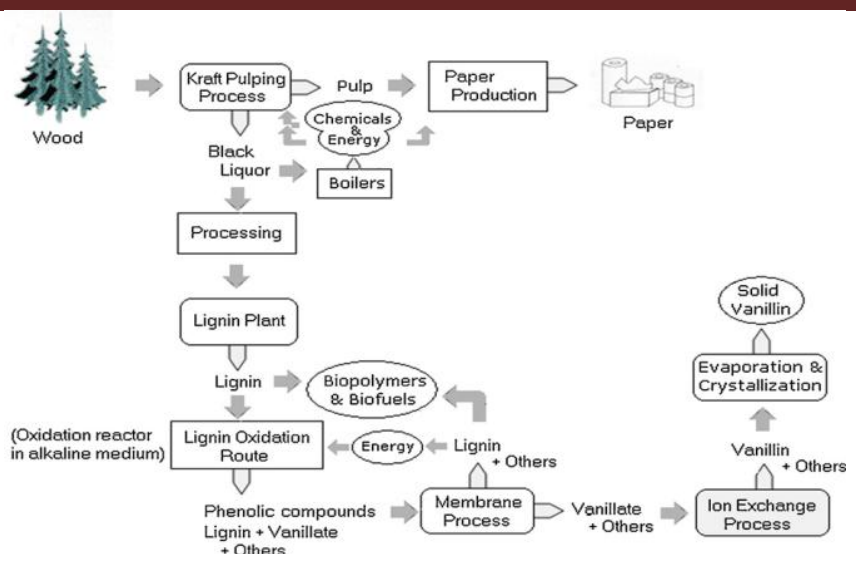

FIG 10:- Valorisation of $K r a f t$ lignin by a biorefinery concept: the proposed integrated process for producing vanillin and biopolymers.

\section{How to reduce cost of Biofuel production from Lignin?}

It is very necessary to reduce cost of biofuel production from lignin to make its reach to each and every hand and also to prtect environment for a sustainable bright future. Some of the techniques to reduce its cost are as following:-

(i) By utilizing the Lignin by product

(ii) By genetically modifying raw material for biofuel production

(iii) By producing useful product along with Biofuel

(iv) By shortening or eliminating Pretreatment steps of raw material

\section{Summary}

The forest biorefinery concept involves converting a pulp mill into a multipurpose biofuels, biomaterials, and biopower production facility in which these products are produced in an environmentally compatible and sustainable manner. We will have to enhance quality of Biofuels for making appreciable use of it. Biofuels are need of present time as fossil fuels are diminishing day by day and we are in search of some alternative to fossil fuels. Biofuels are a medium for getting a prosperous future without pollution. Dawn of Biofuels has already been occur and the day is not so far when each and every vehicle will get driving energy from Biofuel.

\section{References}

1 EERE (2005). U.S. Department of Energy/Energy Efficiency and Renewable Energy http://www.eere.energy.gov/biomass/biomass_benefits.html (October, 2009).

2 Brunow G, Lundquist K, Gellerstedt G. Lignin; Analytical Methods in Wood Chemistry. In: Pulping, and Papermaking. Sjostrom E (ed.), p. 77-124. Berlin: Springer, 1999.

3 Knothe G. Analyzing biodiesel: standards and other methods. J Am Oil Chem Soc 2006; 83(10):823-33.

4 Ralph J, Lundquist K, Brunow G, Lu F, Kim H, Schatz P.F, Marita J.M, Hatfield, R.D, 
Ralph S.A, Christensen J.H, Boerjan W. Lignins: Natural polymers from oxidative coupling of 4-hydroxyphenyl- propanoids. Phytochem Rev 2004;3(1-2):29-60.

5 Gang DR, Costa MA, Fujita M, Dinkova-Kostova AT, Wang HB, Burlat V, Martin W, Sarkanen S, Davin LB, Lewis NG. Regiochemical control of monolignol radical coupling: A new paradigm for lignin and lignan biosynthesis. Chem Biol 1999;6(3):143-51.

6 John R, Knut L, Gosta B, Fachuang L, Hoon K, Paul FS, Jane MM, Ronald DH, Sally AR, Jorgen HC, Wout B. Lignins: Natural polymers from oxidative coupling of 4-hydroxyphenylpropanoids. Phytochem Rev 2004;3(1-2):29-60.

7 Ragauskas AJ, Williams CK, Davison BH, Britovsek G, Cairney J, Eckert CA, Frederick W Jr, Hallett JP, Leak DJ, Liotta CL, Mielenz JR, Murphy R, Templer R, Tschaplinski T. The Path Forward for Biofuels and Biomaterials. Science 2006;311(5760):484-9.

8 DOE. Carbon Cycling and Biosequestration, Integration Biology and Climate Through Systems Science DOE/SC-108; DOE Office of Science: Washington, 2008 see also:http://genomicsgtl.energy.gov/carboncycle/ (July, 2009).

9 Boden, TA., Marland G, Andres RJ. Global, Regional, and National Fossil-Fuel CO2 Emissions. Carbon Dioxide Information Analysis Center., Oak Ridge: ORNL, USDE 2009.

10 DOE. Bioethanol; Moving into the marketplace DOE/GO-102000-1109; DOE Office of Science: Washington, 2000.

11 EIA (Energy Information Administration): http://www.eia.doe.gov/emeu/international/ petroleu.html\#IntlConsumption (Jan. 29, 2005).

12 Hirsch RL, Bezdek R, Wendling R. Peaking of world oil production and its mitigation. AIChE Journal 2006;52(1):2-8.

13 Pacala S, Socolow R. Stabilization wedges: Solving the climate problem for the next 50 years with current technologies. Science 2004;305(5686):968-72.

14 CADIA (Carbon Dioxide Information Analysis Center) data base:http://cadiac.ornl.gov (October, 2009).

15 Hoffert MI, Caldeira K, Benford G, Criswell DR, Green C, Herzog H, Jain AK, Kheshgi HS, Lackner KS, Lewis JS, Lightfoot HD, Manheimer W, Mankins JC, Mauel ME, Perkins LJ, Schlesinger ME, Volk T, Wigley TML. Advanced technology paths to global climate stability: Energy for a greenhouse planet. Science 2002;298(5595):981-87.

16 Pacala S, Socolow, R. Stabilization wedges: Solving the climate problem for the next 50 years with current technologies. Science 2004;305(5686):968-72.

17 Chakar FS, Ragauskas AJ. Review of current and futures of wood kraft lignin process chemistry. Ind Crops Prod 2004;20:131-41.

18 Fry SC. Primary cell wall metabolism: Tracking the careers of wall polymers in living 
plant cells. New Phytol 2004;161(3):641-75.

19 Fratzl P. Cellulose and collagen: from fibers to tissues. Curr Op Coll Interf Sci 2003;8(1):32-9.

20 Reiter WD. Biosynthesis and properties of the plant cell wall. Curr Op Plant Biol 2002;5(6):536-42.

21 Luotfi $\mathrm{H}$, Blackwell B, Uloth V. Lignin recovery from kraft black liquor: preliminary process design. TAPPI J 1991:74(1):203-10.

22 Ohman F, Theliander H, Tomani P, Axegard P, Patent WO 2006/031175 A1, 2006.

23 Alen R, Sjostrom E, Vaskikari P. Carbon dioxide precipitation of lignin from alkaline pulping liquors. Cellulose Chem Technol 1985;19(5):537-41.

24 Froass P, Ragauskas AJ, Jiang JE. NMR Studies Part 3: Analysis of Lignins from Modern Kraft Pulping Technologies. Holzforschung 1998;52(4):385-90.

25 Máté Nagy, Biofuel from Lignin \& novel biodiesel analysis, (December 2009), 47.

26 Schweers W. Hydrogenolysis of lignin. III. Comparative hydration of 4-alkylphenols and 4-alkylguiacols. Holzforschung 1969;23:120-7.

27 Hastbacka K, Bredenberg JBS. Hydrocracking of lignin tar and lignin model compounds. Pap Puu 1973;55:129-34.

28 Stray G, Cassidy PJ, Jackson WR, Larkins FP, Sutton JF. Studies related to the structure and reactivity of coals. 11. The hydrogenation of lignin. Fuel 1986;65:1524-30.

29 Wong TYH, Pratt R, Leonog CG, James BR, Hu TQ. Catalytic hydrogenation oflignin aromatics using Ru-arene complexes. Chem Ind 2001;82:255-66.

$30 \mathrm{Hu}$ TQ, James BR. Catalytic modification and photostabilization of lignin functional groups. In: Chemical modification, properties, and usage of lignin. Ed. Hu TQ, p. 24765,New York: Kluwer Academic/Plenum Publishers, 2002.

31 Gierer J. The chemistry of delignification. Holzforschung 1982;36:43-51.

32 Motoyoshi O, Kan K. Liquefaction of lignin: Production of raw materials for organic synthesis by high pressure hydrogenation of lignin. In; Annual report of the Noguchi Institute. Ed. 9, Tokyo: The Noguchi Institute, 1960.

33 Gayubo AG, Aguayo AT, Atutxa A, Aguado R, Bilbao J. Transformation of Oxygenate Components of Biomass Pyrolysis Oil on a HZSM-5 Zeolite. I. Alcohols and Phenols. Ind Eng Chem Res 2004;43:2610-8.

34 Gayubo AG, Aguayo AT, Atutxa A, Aguado R, Bilbao J. Transformation of Oxygenate Components of Biomass Pyrolysis Oil on a HZSM-5 Zeolite. II. Aldehydes, Ketones, and 
Acids. Ind Eng Chem Res 2004;43:2619-26.

35 Vitolo S, Bresci B, Seggiani M, GalloMG. Catalytic upgrading of pyrolytic oils over HZSM-5 zeolite: behaviour of the catalyst when used in repeated upgrading-regenerating cycles. Fuel 2001;80:17-26.

36 Gayubo AG, Aguayo AT, Atutxa A, Aguado R, Bilbao J. Transformation of Oxygenate Components of Biomass Pyrolysis Oil on a HZSM-5 Zeolite. I. Alcohols and Phenols. Ind Eng Chem Res 2004;43:2610-8.

37 Hongzhi Wang1, Yingxi Xue1, Yajuan Chen, Ruifen Li, Jianhua Wei. Lignin modification improves the biofuel production potential in transgenic Populus tomentosa. Beijing Agro Biotechnology Research Center, Beijing Academy of Agriculture and Forestry Sciences, Beijing 100097, China, 11 January 2012.

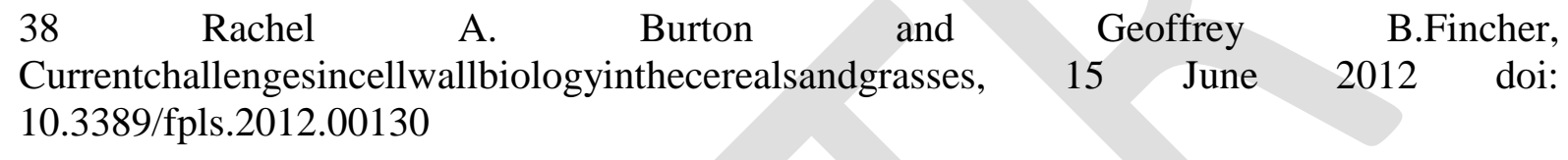

39 Ohman, F., Wallmo, H. and Theliander, H., 2006, An improved method for washing lignin precipitated from Kraft black liquor - The key to a new bio-fuel (http://www.lignoboost.com). In: 5th Conference on Chemical Industry and Environment, Vienna, Austria.

40 Araujo, J.D.P., 2008, Processo de Produc, ao de Vanilina a Partir do Licor Negro das Industrias da Pasta de Papel, Ph.D. thesis, University of Porto, Porto, Portugal.

41 Zabkova, M., da Silva, E.A.B. and Rodrigues, A.E., 2007, Recovery of vanillin from kraft lignin oxidation by ion-exchange with neutralization. Sep Purif Technol, 55(1): 56-68.

42 Zabkova, M., da Silva, E.A.B. and Rodrigues, A.E., 2007, Recovery of vanillin from lignin/vanillin mixture by using tubular ceramic ultrafiltration membranes. J Membr Sci, 301(1-2): 221-237.

43 Cateto, C.A., Barreiro, M.F., Rodrigues, A.E. and Belgacem, M.N., 2007, Oxypropylation of lignins and characterization of the ensuing polyols, In Proceedings of the 8th ILI Forum , pp. 115-119. 